\title{
Alginate-pomegranate peels' polyphenols beads: effects of formulation parameters on loading efficiency
}

\author{
Wissam Zam1,", Ghada Bashour ${ }^{1}$, Wassim Abdelwahed ${ }^{2}$, Warid Khayata ${ }^{1}$ \\ ${ }^{1}$ Department of Analytical and Food Chemistry, Faculty of Pharmacy, University of Aleppo, Syrian Arab Republic, \\ ${ }^{2}$ Department of Pharmaceutical Technology, Faculty of Pharmacy, University of Aleppo, Syrian Arab Republic
}

\begin{abstract}
Calcium alginate beads containing pomegranate peels' polyphenol extract were encapsulated by ionic gelation method. The effects of various formulation factors (sodium alginate concentration, calcium chloride concentration, calcium chloride exposure time, gelling bath time maintaining, and extract concentration) on the efficiency of extract loading were investigated. The formulation containing an extract of $1 \mathrm{~g}$ pomegranate peels in $100 \mathrm{~mL}$ distilled water encapsulated with $3 \%$ of sodium alginate cured in $0.05 \mathrm{M}$ calcium chloride for 20 minutes and kept in a gelling bath for 15 minutes was chosen as the best formula regarding the loading efficiency. These optimized conditions allowed the encapsulation of $43.90 \%$ of total extracted polyphenols and $46.34 \%$ of total extracted proanthocyanidins. Microencapsulation of pomegranate peels' extract in calcium alginate beads is a promising technique for pharmaceutical and food supplementation with natural antioxidants.
\end{abstract}

Uniterms: Pomegranate/polyphenols/microencapsulation. Calcium alginate beads/microencapsulation. Microencapsulation. Polyphenols. Natural antioxidants/microencapsulation.

Pérolas de alginato de cálcio, contendo polifenóis de extrato de casca de romã, foram encapsuladas pelo método de gelificação iônica. Os efeitos de vários fatores de formulação (concentração de alginato de sódio, concentração de cloreto de cálcio, cloreto de cálcio, o tempo de exposição, o tempo de manutenção do banho de gelificação e a concentração do extrato) sobre a eficiência de carga do extrato foram investigados. A formulação que contém $1 \mathrm{~g}$ extrato de casca de romã em $100 \mathrm{~mL}$ de água destilada, encapsulado com 3\% de alginato de sódio curada em $0,05 \mathrm{M}$ de cloreto de cálcio durante 20 minutos e mantido em banho de gelificação por 15 min foi escolhida como a melhor em relação à eficiência de carga. Estas condições otimizadas permitem o encapsulamento de $43,90 \%$ do total de polifenóis extraídos e de $46,34 \%$ do total de proantocianidinas extraídas. A microencapsulação de extrato de cascas de romã em esferas de alginato de cálcio é uma técnica promissora para a suplementação farmacêutica e de alimentos com antioxidantes naturais.

Unitermos: Romã/polifenóis/microencapsulação. Alginato de cálcio/microencapsulação. Microencapsulação. Polifenóis. Antioxidantes naturais/microencapsulação.

\section{INTRODUCTION}

Pomegranate peels (Punica granatum) contain a high amount of polyphenols associated with free radical scavenging activity. Epidemiological studies have revealed that consumption of polyphenols correlates with reduced cardio- and cerebro-vascular diseases and

\footnotetext{
*Correspondence: Wissam Zam. Department of Analytical and Food Chemistry, Faculty of Pharmacy, University of Aleppo, Aleppo, Syrian Arab Republic. E-mail: ws.sarah2005@gmail.com
}

cancer mortality (Lansky, Newman, 2007; Shabtay et al., 2008).

Natural polyphenols extracted from pomegranate peels should be protected from the surrounding medium because they are very sensitive to oxygen, light, acid, and alkaline, but relatively less sensitive to heat. Therefore, the administration of phenolic compounds requires the formulation of a finished protecting products able to maintain the structural integrity of the polyphenol until the consumption, mask its taste, and increase its water solubility and bioavailability. 
Among the existing stabilization methods, encapsulation is an interesting means. Conventional microencapsulation as described by Swapan (2006) is a process of surrounding either a liquid droplet or a solid particle core with a defined, solid shell. It is used to either deliver, protect, stabilize or control the release of the core.

There have been a number of recent reviews focusing on the encapsulation of the more widely used polyphenols, discussing their effectiveness, variations, developments and trends (Barras et al., 2009; Das, Ng, 2010; Di Mattia et al., 2009; Dube et al., 2010; Ersus, Yurdagel, 2007; Fang et al., 2006; Hu et al., 2008; Kosaraju, Dath, Lawrence, 2006; Laine et al., 2008; Liang et al., 2011; Lucas-Abellan et al., 2007; Mourtzinos et al., 2007; Shi et al., 2007; Shutava et al., 2009; Tommasini et al., 2005; Zhang, Mou, Du, 2007; Xiong et al., 2006; Yu, Huang, 2010).

The ionic gelation process, one of the physicochemical methods used in microencapsulation, consists of extruding an aqueous solution of polymer through a syringe needle or a nozzle, in which the active material is dissolved or dispersed. Droplets are received in a dispersant phase and are transformed, after reaction, into spherical gel particles, as is the case, for example, with sodium alginate used with a dispersant phase of calcium chloride (Vandamme, Poncelet, Subra-Paternault, 2007).

The encapsulating agent used in this study was sodium alginate. It is an anionic polymer which can be easily cross-linked with calcium chloride, this is because the calcium ions are bound to carboxylate residues of both mannuronic acid and glucournic acid which are components of sodium alginate (Ravindra, Sabitha, 2010). Sodium alginate is a hygroscopic material, although it is stable if stored at relatively low humidity and a cool temperature. Aqueous solutions of sodium alginate are most stable at $\mathrm{pH} 4-10$. Below $\mathrm{pH} 3$, alginic acid is precipitated (Raymond, Paul, Marian, 2009). It is generally regarded as a nontoxic and nonirritant material, it is GRAS listed (Generally Recognised As Safe), and accepted in Europe for use as a food additive. Although excessive oral consumption may be harmful, the World Health Organization (WHO) has not specified an acceptable daily intake for alginic acid and alginate salts as the levels used in food do not represent a hazard to health (Raymond, Paul, Marian, 2009).

Thus the objective of this study is to encapsulate the polyphenol extract in calcium alginate beads to be incorporated as an additive in pharmaceutical or food products.

The effects of various formulation factors (sodium alginate concentration, calcium chloride concentration, calcium chloride exposure time, gelling bath time maintaining, extract concentration, and additives type) on the efficiency of extract loading were investigated.

\section{MATERIAL AND METHODS}

\section{Chemical and reagents}

Sodium alginate and Folin-Ciocalteu reagent $2 \mathrm{~N}$ were obtained from Sigma-Aldrich (Switzerland);calcium chloride, sodium chloride and tri-sodium citrate were obtained from Riedel-de-Haen (Germany); ferric ammonium sulfate (Carl Roth, Germany); sodium carbonate anhydrous, 1-butanol and hydrochloric acid were obtained from Surechem (England).

\section{Sample preparation}

Fresh pomegranates were cleaned with water and dried with a cloth. The peels were manually separated, dried for a few days in an open air shade. The dried samples were then powdered in a blender. They were stored at $-18^{\circ} \mathrm{C}$ until analysis (Zam et al., 2012).

\section{Extraction procedure}

$2 \mathrm{~g}$ of dried and ground peel were placed in a thermostatic water bath shaker with $100 \mathrm{~mL}$ of distilled water at $50{ }^{\circ} \mathrm{C}$ for 20 minutes. The liquid extract was separated from solids by centrifugation at $2000 \mathrm{rpm}$ for 10 minutes. The supernatant was transferred to a $100 \mathrm{~mL}$ flask, and distilled water was added to make the final volume $100 \mathrm{~mL}$ (Zam et al., 2012).

\section{Optimization of loading efficiency}

The formulation of the calcium alginate beads is based on both the concentration of sodium alginate and the ability of calcium ions to cross link with sodium alginate. The degree of cross linking is dependent on both the concentration of the calcium chloride solution and the time of contact of the beads with this solution. To optimize the parameters affecting the formulation of beads, various factors were evaluated: sodium alginate concentration (1-4.5\%), calcium chloride concentration (0.01-0.1 M), calcium chloride exposure time (5-60 minutes), gelling bath time maintaining (5-60 minutes), and extract concentration $(0.25-2.5 \%)$.

\section{Capsules formulation}

Beads were obtained by mixing $10 \mathrm{~mL}$ of the active 
component with $10 \mathrm{~mL}$ of the sodium alginate solution at the best concentration. Once homogenized, $10 \mathrm{~mL}$ of calcium chloride solution at the best concentration was added to the alginate solution and was cured for different duration to optimize curing time at $25{ }^{\circ} \mathrm{C}$. The beads formed in this process were maintained in the gelling bath to harden. Then, they were centrifuged at 4,000 rpm and $4{ }^{\circ} \mathrm{C}$ for 15 minutes (Anbinder et al., 2011).

\section{Loading efficiency}

The amount of lyophilized extract loaded in beads was estimated, as described by Deladino et al. (2007), by dissolving the capsules obtained from $10 \mathrm{~mL}$ extract in sodium citrate $(10 \% \mathrm{w} / \mathrm{v})$ during a period of $20 \mathrm{~min}$ for alginate capsules in a shaker at $37^{\circ} \mathrm{C}$ and $125 \mathrm{rpm}$. The concentrations of lyophilized extract loaded in the beads were determined by Folin-Ciocalteu and butanol assay method. A blank of sodium citrate was also performed. The percentage of loading efficiency was calculated with the following equation:

$$
\text { Loading efficiency }(\%)=\frac{\boldsymbol{L}}{\boldsymbol{L}_{0}} * 100
$$

where $\mathrm{L}$ is the amount of extract determined on the solution of sodium citrate and $\mathrm{L}_{0}$ is the initial amount of extract dissolved in the alginate solution (Deladino et al., 2007).

\section{Total polyphenol content}

The total polyphenol content in the extract was determined by the Folin-Ciocalteu method according to the method described by the International Organization for Standardization (ISO, 2005). A sample of $250 \mu \mathrm{L}$ of the extract was diluted with distilled water to $10 \mathrm{~mL}$. Aliquots of $1 \mathrm{~mL}$ of samples were mixed with $5 \mathrm{~mL}$ of 10 -folddiluted Folin-Ciocalteu reagent. After 3 minutes, $4 \mathrm{~mL}$ of $7.5 \%$ sodium carbonate was added (Zahin, Aqil, Ahmad, 2009). The mixtures were allowed to stand for 30 minutes at $40{ }^{\circ} \mathrm{C}$ temperature (water bath) before the absorbance was measured at $734 \mathrm{~nm}$ using Jasco V-530 spectrophotometer. The total polyphenol content in the extract was calculated and expressed as gallic acid equivalents (GAE; g/100 g dry mass) using a gallic acid (0-120 mg/L) standard curve (Anesini, Ferraro, Filip, 2008).

\section{Proanthocyanidins content}

The proanthocyanidin content in the extract was determined by the Acid Butanol assay according to the method of Porter et al. (1986). A sample of $200 \mu \mathrm{L}$ extract diluted with $300 \mu \mathrm{L}$ of acetone $70 \%$ was pipetted into a $100 \times 12 \mathrm{~mm}$ test tube. $3.0 \mathrm{~mL}$ of butanol-HCL reagent (95:5) and $0.1 \mathrm{~mL}$ of $2 \%$ ferric acid prepared in $\mathrm{HCl} 2 \mathrm{~N}$ were added. The tube was vortexed and then the mouth of the tube was covered with a glass marble and put in the heating block at 97 to $100{ }^{\circ} \mathrm{C}$ for 60 minutes. The tube was then allowed to cool and absorbance was recorded at $550 \mathrm{~nm}$. The formula for calculating percentage of condensed tannins as leucoanthocyanidin equivalent is:

\section{(absorbance $550 \mathrm{~nm}^{*} 78.26 *$ dilution factor) dry matter \%}

\section{RESULTS AND DISCUSSION}

\section{Sodium alginate concentration}

Different concentrations of sodium alginate were examined namely: $1,1.5,2,2.5,3,3.5,4$ and $4.5 \%(\mathrm{w} / \mathrm{v})$, (calcium chloride $0.05 \mathrm{~mol} / \mathrm{L}$ as a cross linking agent for 15 minutes and the beads formed in this process were maintained in the gelling bath to harden for 15 minutes).

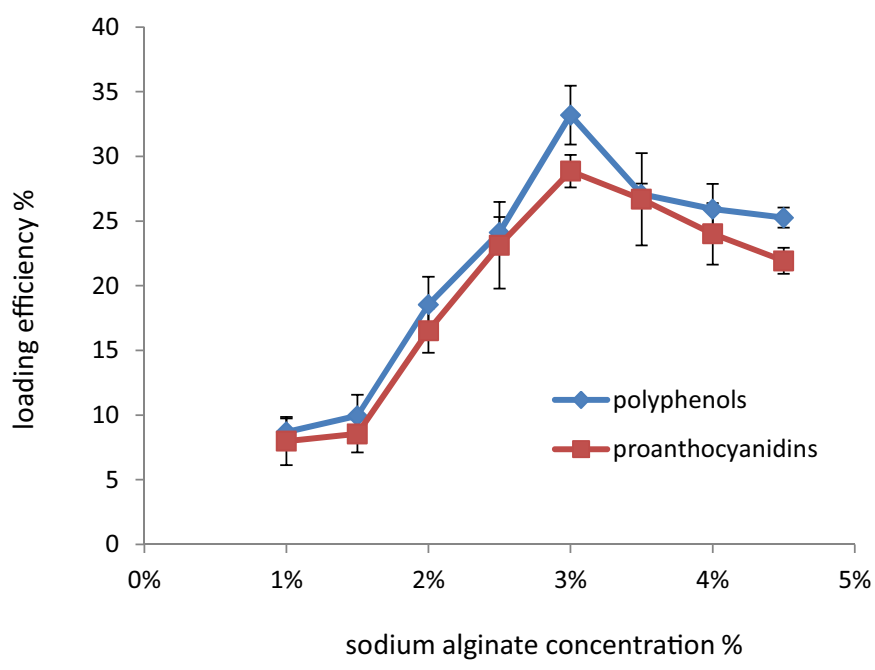

FIGURE 1 - Effect of sodium alginate concentration on total extractable polyphenols and proanthocyanidins loading efficiency. ${ }^{a}$ Values are mean $\pm \mathrm{SD},(\mathrm{n}=3)$.

Results obtained showed that increasing sodium alginate concentration from $1 \%$ to $3 \%$ elevated loading efficiency from approximately 8 to $33 \%$ (Figure 1). The concentration of $3 \%$ gave the best loading efficiency for both total extractable polyphenols and proanthocyanidins, with values of $33.19 \% \pm 0.014$ and $28.85 \% \pm 0.012$, respectively (Figure 1). As reported by El-Kamel et al. (2003), this may be attributed to the greater availability 
of active calcium-binding sites in the polymeric chains and, consequently, the greater degree of cross linking as the quantity of sodium alginate increased.

Higher concentration of sodium alginate is accompanied by an increase in viscosity and a decrease in loading efficiency. Based on this result, for the next experiment, the concentration of alginate was $3 \%(\mathrm{w} / \mathrm{v})$, because this concentration is the lowest concentration which can make a good loading efficiency. The concentration of alginate utilized in this study was higher than the one used by Deladino et al. $(2 \%, \mathrm{w} / \mathrm{v})$ for the encapsulation of polyphenols extracted from yerba mate.

\section{Calcium chloride concentration}

Alginate solution droplets in this experiment are gelled by contact with calcium chloride solution droplets. The concentration of calcium chloride has an important influence on the characteristics of the resulting alginate beads.

Therefore, we examined the effect of the concentration of calcium chloride on alginate bead loading efficiency. The concentration of sodium alginate solution was fixed at $3 \%$, curing time after addition of calcium chloride was 15 min and hardening time in gelling bath was also $15 \mathrm{~min}$. The concentration of calcium chloride varied from $0.01 \mathrm{M}$ to $0.1 \mathrm{M}$.

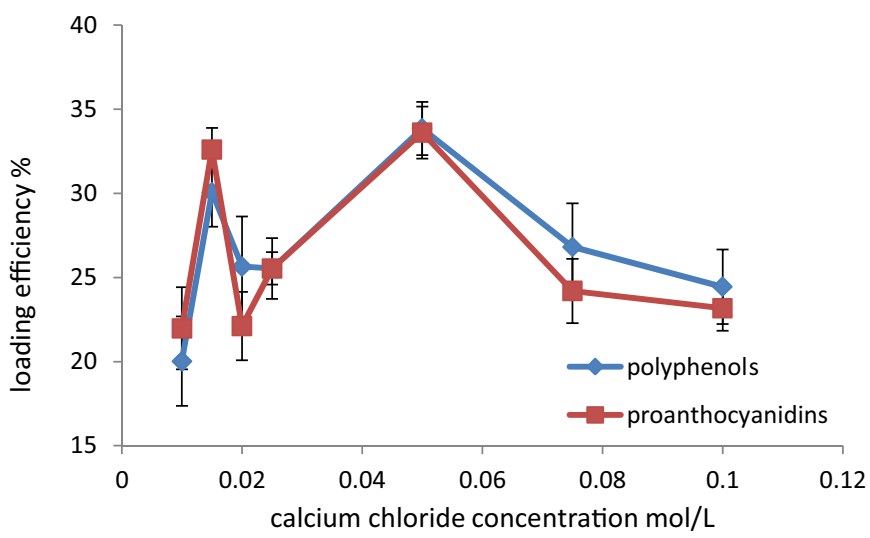

FIGURE 2 - Effect of calcium chloride concentration on total extractable polyphenols and proanthocyanidins loading efficiency. ${ }^{a}$ Values are mean $\pm \mathrm{SD},(\mathrm{n}=3)$.

Results obtained showed that increasing calcium chloride concentration from $0.01 \mathrm{M}$ to $0.05 \mathrm{M}$ elevated loading efficiency from approximately 20 to $34 \%$ (Figure $2)$. This may be explained by the increase in the gel strength as the calcium ions increased. The concentration of $0.05 \mathrm{M}$ gave the best loading efficiency for both total extractable polyphenols and proanthocyanidins, with values of $33.84 \% \pm 0.007$ and $33.61 \% \pm 0.012$, respectively (Figure 2). These results are in agreement with Takka et al. (1998) and Mirghani et al. (2000).

On the other hand, the loading efficiency was found to decrease at concentrations of more than $0.05 \mathrm{M}$, this may indicate damage of microcapsules due to possible saturation of calcium binding sites in the glucoronic acid chain, preventing further calcium ion entrapment as reported by Ostberg et al (1994) or to osmotic stress as reported by Takayuki et al. (2009). Based on these results, we adopted a concentration of $0.05 \mathrm{M}$ in subsequent experiments.

\section{Calcium chloride exposure time}

King (1983) suggested that, when calcium and alginate solutions get in contact, a gel is formed immediately at the interface, thus matrix homogeneity depends on the calcium diffusion through the gel network. Continuous exposure of the alginate to the calcium solution will increase the firmness of the gel, as more calcium diffuses into the gel and binds to the $\mathrm{G}$ blocks within the alginate structure (Lamkey et al., 2009). Diffusion of calcium chloride towards the beads core, at 5 , $10,15,20,25,30,45,60 \mathrm{~min}$, was examined and loading efficiency values were demonstrated in Figure 3.

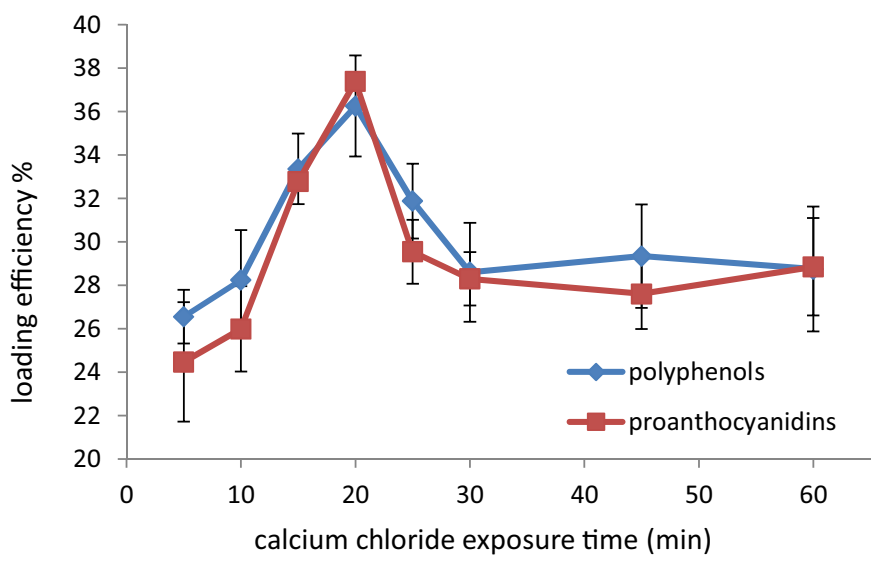

FIGURE 3 - Effect of calcium chloride exposure time on total extractable polyphenols and proanthocyanidins loading efficiency. ${ }^{a}$ Values are mean $\pm \mathrm{SD},(\mathrm{n}=3)$.

Thus, $20 \mathrm{~min}$ in air was enough to get the best loading efficiency for both total extractable polyphenols and proanthocyanidins, with values of $36.25 \% \pm 0.010$ and $37.39 \% \pm 0.009$, respectively (Figure 3 ).

Patel et al. (2006), showed that the loading efficiency of calcium alginate beads containing metronidazole 
decreased with increase in curing time, this could be explained that longer times could cause the shift of the bounded calcium ions by alginate as reported by ElDeladino et al. (2007) or may be due to the increased release of polyphenols from the matrix as reported by El-Kamel et al. (2003).

\section{Gelling bath time maintaining}

The beads formed were maintained in the gelling bath to harden for different times (5-60 min).

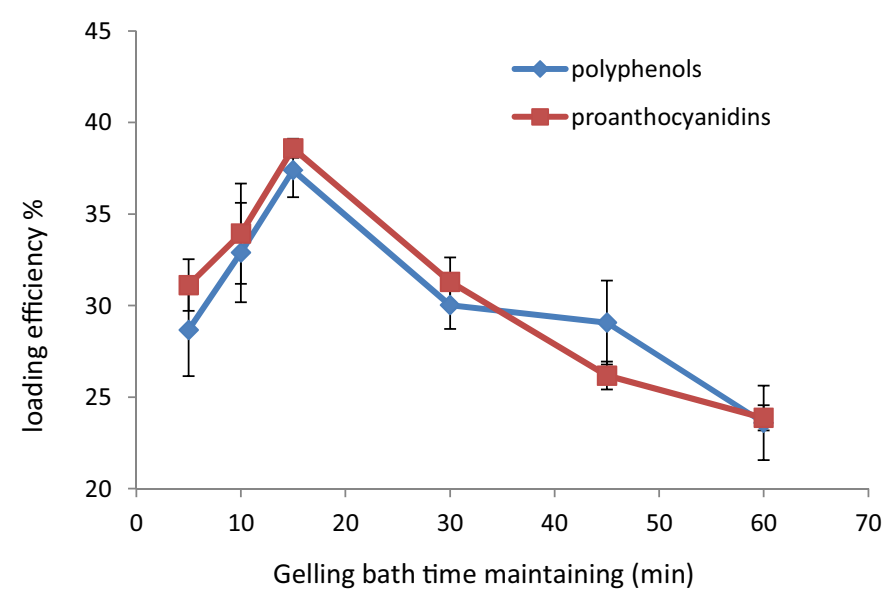

FIGURE 4 - Effect of gelling bath time maintaining on total extractable polyphenols and proanthocyanidins loading efficiency. ${ }^{a}$ Values are mean $\pm \mathrm{SD},(\mathrm{n}=3)$.

Results obtained showed that increasing maintaining time from 5 min to 15 min elevated loading efficiency from approximately 28 to $37 \%$ (Figure 4 ). This may be explained by the increase in the gel strength as the time increased. The maintaining time of 15 minutes gave the best loading efficiency for both total extractable polyphenols and proanthocyanidins, with values of $37.39 \% \pm 0.007$ and $38.59 \% \pm 0.010$, respectively (Figure 4 ).

Results also showed that the loading efficiency of calcium alginate beads decreased with an increase in maintaining time in the gelling bath because longer times could increase the release of polyphenols from the matrix. These results are in agreement with Anbinder et al. (2011).

\section{Extract concentration}

When the amount of drug is greater, lesser amount of drug diffusion in surrounding aqueous medium was taken place during a definite curing time as mentioned by Jaiswal et al. (2009). Trivedi et al (2008) prepared aceclofenac microspheres by emulsion-solvent evaporation, results from this study clearly indicate that encapsulation efficiency is significantly increase as the drug:polymer ratio decreased.

After the above decision, the effect of total extractable polyphenols concentration in preparation of microcapsules was analyzed. The results showed that when the concentration of polyphenols increased, the loading efficiency decreased at the same amount of polymer in the dispersed (Table I).

Based on these results, the best extract concentration leading to the highest loading efficiency was prepared using $1 \mathrm{~g}$ of finely ground pomegranate peels extracted with $100 \mathrm{~mL}$ of distilled water.

In conclusion, we optimized the preparation parameters for polyphenols alginate gel beads by ionic gelation method with a view to large-scale production. The optimized concentrations of sodium alginate and calcium chloride in the aqueous phases, curing time and gelling bath maintaining time, extract concentration were $3 \%(\mathrm{w} / \mathrm{v}), 0.05 \mathrm{M}, 20 \mathrm{~min}, 15 \mathrm{~min}$ and $1 \mathrm{~g} / 100 \mathrm{~mL}$, respectively. The mean loading efficiency was $43.90 \% \pm$ 0.006 for total extracted polyphenols and $46.34 \% \pm 0.011$ for total extracted proanthocyanidins. Optical microscope was used to investigate the shape of microcapsules prepared by the proposed method. Photos indicate that the microcapsules were covered continuously with sodium alginate coat material (Figure 5).

TABLE I - Effect of extract concentration on total extractable polyphenols and proanthocyanidins loading efficiency

\begin{tabular}{ccc}
\hline Extract concentration & Loading efficiency Polyphenols $^{a}$ & Loading efficiency Proanthocyanidins $^{a}$ \\
\hline $0.25 \mathrm{~g} / 100 \mathrm{~mL}$ & $35.50 \% \pm 0.001$ & $36.58 \% \pm 0.006$ \\
$0.5 \mathrm{~g} / 100 \mathrm{~mL}$ & $43.40 \% \pm 0.003$ & $45.49 \% \pm 0.011$ \\
$1 \mathrm{~g} / 100 \mathrm{~mL}$ & $43.92 \% \pm 0.006$ & $46.34 \% \pm 0.011$ \\
$1.5 \mathrm{~g} / 100 \mathrm{~mL}$ & $37.30 \% \pm 0.015$ & $37.04 \% \pm 0.009$ \\
$2 \mathrm{~g} / 100 \mathrm{~mL}$ & $37.39 \% \pm 0.007$ & $38.59 \% \pm 0.010$ \\
$2.5 \mathrm{~g} / 100 \mathrm{~mL}$ & $32.89 \% \pm 0.027$ & $31.89 \% \pm 0.009$ \\
\hline
\end{tabular}

${ }^{a}$ Values are mean $\pm \mathrm{SD},(\mathrm{n}=3)$ 


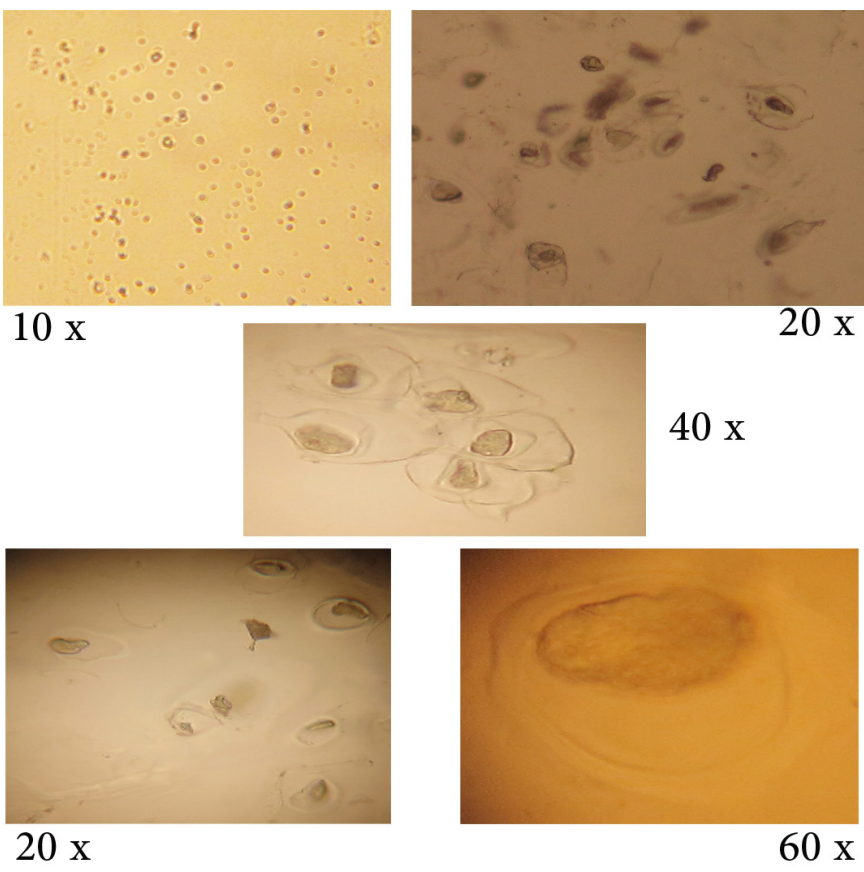

FIGURE 5 - Optical microscope photograph of calcium alginate beads containing pomegranate peels' polyphenol extract.

\section{CONCLUSION}

This study shows that calcium alginate microcapsules could be a good carrier for polyphenols. This method of preparation of microcapsules containing pomegranate peels' polyphenol was found to be simple, rapid and reproducible. The protective effect of microencapsulation will help to produce pharmaceutical and food supplements which can improve the physiological efficiency of polyphenols.

\section{ACKNOWLEDGMENT}

This work was funded by the Faculty of PharmacyUniversity of Aleppo- Syrian Arab Republic. The authors would like to thank D. Jamil Daher and Al-Andalus Language Center for their linguistic assistance.

\section{REFERENCES}

ANESINI, C.; FERRARO, G.E.; FILIP, R. Total polyphenol content and antioxidant capacity of commercially available tea (Camellia sinensis) in Argentin. J. Agric. Food Chem., v.56, p.9225-9229, 2008.

ANBINDER, P.S.; DELADINO, L.; NAVARRO, A.S.; AMALVY, J.I.; MARTINO, M.N. Yerba mate extract encapsulation with alginate and chitosan systems: interactions between active compound encapsulation polymers. JEAS, v.1, p.80-87, 2011.
BARRAS, A.; MEZZETTI, A.; RICHARD, A.; LAZZARONI, S.; ROUX, S.; MELNYK, P. Formulation and characterization of polyphenol-loaded lipid nanocapsules. Int. J. Pharm., v.379, p.270-277, 2009.

DAS, S.; NG, K.Y. Resveratrol-loaded calcium-pectinate beads: Effects of formulation parameters on drug release and bead characteristics. J. Pharm. Sci., v.99, p.840-860, 2010.

DELADINO, L.; ANBINDER, P.S.; NAVARRO, A.S.; MARTINO, M.N. Encapsulation of natural antioxidants extracted from Ilex paraguariensis. Carbohydr. Polym., v.71, p.126-134, 2007.

DI MATTIA, C.D.; SACCHETTI, G.; MASTROCOLA, D.; PITTIA, P. Effect of phenolic antioxidants on the dispersion state and chemical stability of olive oil $\mathrm{O} / \mathrm{W}$ emulsions. Food Res. Int., v.42, p.1163-1170, 2009.

DUBE, A.; NG, K.; NICOLAZZO, J.A.; LARSON, I. Effective use of reducing agents and nanoparticle encapsulation in stabilizing catechins in alkaline solution. Food Chem., v.122, p.662-667, 2010.

EL-KAMEL, A.H.; AL-GOHARY, O.M.N; HOSNY, E.A. Alginate-diltiazem hydrochloride beads: optimization of formulation factors, in vitro and in vivo availability. $J$. Microencapsul., v.20, p.211-225, 2003.

ERSUS, S.; YURDAGEL, U. Microencapsulation of anthocyanin pigments of black carrot (Daucus carota L.) by spray drier. J. Food Eng., v.80, p.805-812, 2007.

FANG, J.Y.; HWANG, T.L.; HUANG, Y.L.; FANG, C.L. Enhancement of the transdermal delivery of catechins by liposomes incorporating anionic surfactants and ethanol. Int. J. Pharm., v.310, p.131-138, 2006.

HU, B.; PAN, C.; SUN, Y.; HOU, Z.; YE, Y. Optimization of fabrication parameters to produce chitosan-tripolyphosphate nanoparticles for delivery of tea catechins. J. Agric. Food Chem., v.56, p.7451-7458, 2008.

ISO 14502-1: 2005. Determination of substances characteristic of green and black tea. Part 1: Content of total polyphenols in tea. Colorimetric method using Folin-Ciocalteu reagent.

JAISWAL, D.; BHATTACHARYA, A.; KUMAR YADAV, I.; PRATAP SINGH, H.; CHANDRA, D.; JAIN, D.A. Formulation and evaluation of oil entrapped floating alginate beads of ranitidine hydrochloride. Int. J. Pharm. Pharm. Sci., v.1, suppl.1, 2009. 
KOSARAJU, S.L.; DATH, L.; LAWRENCE, A. Preparation and characterisation of chitosan microspheres for antioxidant delivery. Carbohydr. Polym., v.64, p.163-167, 2006.

LIANG, J.; LI, F.; FANG, Y.; YANG, W.; AN, X.; ZHAO, L.; XIN, Z.; CAO, L.; HU, Q. Synthesis, characterization and cytotoxicity studies of chitosan-coated tea polyphenols nanoparticles. Colloids Surf. B: Biointerfaces, v.82, p.297301, 2011.

LAMKEY, J.W. Nonstarch hydrocolloids. In: RODRIGO, T. Ingredients in meat products: properties, functionality and applications. Springer, 2009. Chap.3, p.57-82.

LANSKY, E.P.; NEWMAN, R.A. Punica granatum (pomegranate) and its potential for prevention and treatment of inflammation and cancer. J. Ethnopharmacol., v.19, p.177-206, 2007.

LAINE, P.; KYLLI, P.; HEINONEN, M.; JOUPPILA, K. Storage stability of microencapsulated cloudberry (Rubus chamaemorus) phenolics. J. Agric. Food Chem., v.56, p.11251-11261, 2008.

LUCAS-ABELLAN, C.; FORTEA, M.I.; LOPEZ-NICOLAS, J.M.; NUNEZ-DELICADO, E. Cyclodextrins as resveratrol carrier system. Food Chem., v.104, p.39-44, 2007.

MIRGHANI, A.; IDKAIDEK, N.M.; SALEM, M.S.; NAJIB, N.M. Formulation and release behavior of diclofenac sodium in compritol matrix beads encapsulated in alginate. Drug Dev. Ind. Pharm., v.26, p.791-795, 2000.

MOURTZINOS, I.; SALTA, F.; YANNAKOPOULOU, K.; CHIOU, A.; KARATHANOS, V.T. Encapsulation of olive leaf extract in beta-cyclodextrin. J. Agric. Food Chem., v.55, p.8088-8094, 2007.

OSTBERG, T.; LUND, M.E.; GRAFFNER, C. Calcium alginate matrices for oral multiple unit administration: Release characteristics in different media. Int. J. Pharm., v.112, p.241-248, 1994.

YAGNESH, L.P.; PRAVEEN, S.; ATMARAM, P.P. The effect of drug concentration and curing time on processing and properties of calcium alginate beads containing metronidazole by response surface methodology. AAPS PharmSciTech., v.7, p.86, 2006.
PORTER, L.J.; HRSTICH, L.N.; CHAN, B.G. The conversion of procyanidins and prodelphinidins to cyanidin and delphinidin. Phytochemistry, v.25, p.223-230, 1986.

RAVINDRA, K.; SABITHA, P. Effect of different co-polymers on sodium alginate microcapsules containing isoniazid. Int. J. Pharm. Tech. Res., v.2, p.2198-2203, 2010.

RAYMOND, C.R.; PAUL, J.S.; MARIAN, E.Q. Handbook of pharmaceutical excipients. 6.ed. London: Pharmaceutical Press and American Pharmacists Association, 2009. 917 p.

SHABTAY, A.; EITAM, H.; TADMOR, Y.; ORLOV, A.; MEIR, A.; WEINBERG, P.; WEINBERG, Z.G.; CHEN, Y.; BROSH, A.; IZHAKI, I.; KEREM, Z. Nutritive and antioxidative potential of fresh and stored pomegranate industrial byproduct as a novel beef cattle feed. J. Agric. Food Chem., v.56, p.10063-10070, 2008.

SHI, G.; RAO, L.; YU, H.; XIANG, H.; PEN, G.; LONG, S. Yeast cell-based microencapsulation of chlorogenic acid as a water-soluble antioxidant. J. Food Eng., v.80, p.10601067, 2007.

SHUTAVA, T.G.; BALKUNDI, S.S.; LVOV, Y.M. Epigallocatechin gallate/gelatin layer-by-layer assembled films and microcapsules. J. Colloid Interface Sci., v.330, p.276-283, 2009.

SHUTAVA, T.G.; BALKUNDI, S.S.; VANGALA, P.; STEFFAN, J.J.; BIGELOW, R.L.; CARDELLI, J.A. Layer-by-layer-coated gelatin nanoparticles as a vehicle for delivery of natural polyphenols. ACS Nano, v.3, p.1877$1885,2009$.

SWAPAN, K.G. Functional coatings by polymer microencapsulation. Germany: Wiley-VCHVerlag $\mathrm{GmbH}$ \& Co. KGaA, 2006. 343 p.

TAKAYUKI, T.; MASAHIRO, Y.; YASUO, H.; KOUICHIRO, S.; SHIRO K. Preparation of lactic acid bacteria-enclosing alginate beads in emulsion system: effect of preparation parameters on bead characteristics. Polym. Bull., v.63, p.599-607, 2009.

TAKKA, S.; OCAK, O.H; ACARTURK, F. Formulation and investigation of nicardipine $\mathrm{HCl}$-alginate gel beads with factorial design-based studies. Eur. J. Pharm. Sci., v.6, p.241-246, 1998. 
TOMMASINI, S.; CALABRO, M.L.; STANCANELLI, R.; DONATO, P.; COSTA, C.; CATANIA, S. The inclusion complexes of hesperetin and its 7-rhamnoglucoside with (2 hydroxypropyl)- $\beta$-cyclodextrin. J. Pharm. Biomed. Anal., v.39, p.572-580, 2005.

TRIVEDI, P; VERMA, AML; GARUD, N. Preparation and characterization of aceclofenac microspheres. Asian J. Pharm., v.2, p.110-115, 2008.

VANDAMME, T.F.; PONCELET, D.; SUBRA-PATERNAULT, P. Microencapsulation: des sciences aux technologies. Paris: Lavoisier Tec \& Doc, 2007. 348 p.

XIONG, S.; MELTON, L.D.; EASTEAL, A.; SIEW, D. Stability and antioxidant activity of black currant anthocyanins in solution and encapsulated in glucan gel. J. Agric. Food Chem., v.54, p.6201-6208, 2006.

YU, H.; HUANG, Q. Enhanced in vitro anti-cancer activity of curcumin encapsulated in hydrophobically modified starch. Food Chem., v.119, p.669-674, 2010.
ZAHIN, M.; AQIL, F.; AHMAD, I. The in vitro antioxidant activity and total phenolic content of four indian medicinal plants. Int. J. Pharm. Pharm. Sci., v.1, suppl.1, p.88-95, 2009.

ZAM, W.; BASHOUR, G.; ABDELWAHED, W.; KHAYATA, W. Effective extraction of polyphenols and proanthocyanidins from pomegranate's peel. Int. J. Pharm. Pharm. Sci., v.4, suppl.3, p.675-682, 2012.

ZHANG, L.; MOU, D.; DU, Y. Procyanidins: extraction and micro-encapsulation. J. Agric. Food Chem., v.87, p.21922197, 2007.

Received for publication on $31^{\text {st }}$ January 2013 Accepted for publication on $28^{\text {th }}$ April 2014 